\title{
EFFECT OF THERMAL TREATMENT ON THE WETTABILITY OF GIANT BAMBOO (DENDROCALAMUS ASPER) AND KAWAYAN TINIK (BAMBUSA BLUMEANA) IN THE PHILIPPINES
}

\author{
Marasigan $\mathrm{OS}^{1, *}$, Razal $\mathrm{RA}^{2} \&$ Alipon $\mathrm{MA}^{3}$ \\ ${ }^{1}$ University of the Philippines Los Baños, College, Laguna 4031 Philippines \\ ${ }^{2}$ Department of Forest Products and Paper Science, University of the Philippines Los Baños, College of Forestry and Natural \\ Resources, College, Laguna 4031 Philippines \\ ${ }^{3}$ Department of Science and Technology Forest Products Research and Development Institute, College, Laguna, 4031 \\ Philippines \\ *osmarasigan@up.edu.ph
}

Submitted February 2020; accepted June 2020

\begin{abstract}
The study was conducted to compare the wettability of Dendrocalamus asper and Bambusa blumeana and to determine thermal treatment effect on the surface property of bamboo. Mature bamboo poles (3 samples per species) were collected from Barangay Masapang, Victoria, Laguna, Philippines. The culms were divided into three height segments representing the bottom, middle and top portions and prepared for the wettability test on the outside layer (towards the skin) and inner surface. The samples for wettability and physical property determination were collected from the middle internode in each portion. Wettability property was determined by the Cosine-Contact Angle (CCA) measurement. ANOVA showed significant differences between species, layers, treated and untreated bamboo and height. The top portion of $D$. asper and the middle portion of B. blumeana had the highest measured contact angles, which were found in the outside layer for both bamboos. Thermal treatment changed the color of both bamboos, decreased their density, and significantly improved the wettability property. The results showed that the $D$. asper contact angle was significantly lower at different height levels and layers than B. blumeana for both untreated and thermally-treated samples.
\end{abstract}

Keywords: Bambusa blumeana, Dendrocalamus asper, contact angle, thermal treatment, wettability

\section{INTRODUGTION}

Bamboo has exceptional and impressive attributes, characteristics and properties, sometimes exceeding trees in several ways (BajaLapis et al. 2016). The compressive and tensile strength of bamboo are almost the same as that of steel; it is considered as the green steel of the $21^{\text {st }}$ century (Gupta et al. 2015). Furthermore, bamboo is recognized as one of the fastestgrowing plants on earth and the best alternative to wood (Wahab et al. 2009). Research on the physical, mechanical, chemical and technological properties of bamboo have resulted in the development of numerous products including engineered bamboo (Anwar et al. 2004).

Engineered bamboo products are recent innovations in the bamboo industry. Bamboo culms are processed into slats, slivers, scraps and spokes, while treated, pressed and laminated bamboo to form planks. The planks are then converted to produce furniture, floor, wall panels and other products.

Giant bamboo (Dendrocalamus asper) and Kawayan tinik (Bambusa blumeana) are the most commonly available local bamboo species used in engineered-bamboo production in the Philippines. B. blumeana was introduced to the Philippines and became naturalized. It is a densely tufted, sympodial type of bamboo with spiny basal branches and a culm height that ranges from 15 to $25 \mathrm{~m}$ and culm diameter ranges from 6 to $10 \mathrm{~cm}$. Its internodal length ranges from 25 to $60 \mathrm{~cm}$ and the culm wall thickness varies from 0.5 to $3 \mathrm{~cm}$ (Roxas 2012). D. asper is also an introduced and naturalized species in the Philippines. It is also a sympodial type of bamboo with culm height ranging from 20 to $30 \mathrm{~m}$ and culm diameter ranging from 8 to $20 \mathrm{~cm}$. Its average internodal length is $42.9 \mathrm{~cm}$ long (Roxas 
2012). Both species grow relatively fast in good soil and produce large diameter culms suitable for engineered bamboo and other structural applications.

In the production of engineered bamboo, determination of wettability property of the material is important. Wettability is a surface condition that determines the extent the fluid drawn by the surface, affecting absorption, adsorption, penetration and spread of adhesive (Marra 1992).

Cosine-Contact Angle (CCA) and Corrected Water-Adsorption Height (CWAH) were the techniques used in measuring the wettability property of materials (Sucipto et al. 2018). However, CCA gave a relatively more accurate value compared to CWAH method. Determining the contact angle was done by measuring the angle formed between the surfaces of the materials with an adhesive liquid that was dropped on the material surface (Sucipto 2009). A small contact angle indicated the material had high wettability property.

Thermal treatment was one of the recent developments that improved the durability and aesthetic value of the engineered bamboo products. In this process, bamboo slats were subjected to high temperature, which "caramelizes" the bamboo fiber resulting in brown hue (Zhang et al. 2013). The treatment also resulted in the modification of the carbohydrates in the bamboo. A reduction in the wettability property was observed after heat treatment of spruce, poplar, beech, pine (Petrissans et al. 2003) and Pinus pinaster and Eucalyptus globules (Esteves et al. 2007). Similar observations were found in Phyllostachys pubescens (Zhang and Yu 2015).

There is limited study on the effect of thermal treatment on the wettability property of $D$. asper and B. blumeana to provide information for prediction of relative adhesion strength values in both untreated and thermally-treated bamboo. Therefore, a study was conducted with three main objectives: a) to compare the wettability property of $D$. asper and $B$. blumeana, b) to determine the influence of height levels, density and layers on the wettability of both species of bamboo, and c) to access the effect of thermal treatment on the wettability property of both bamboo species.

\section{MATERIALS AND METHODS}

\section{Raw materials}

Two species of bamboo were used in this study namely, $D$. asper and $B$. blumeana. The mature culms of $D$. asper and B. blumeana were collected from Barangay Masapang, Victoria, Laguna, Philippines. For each species, culms with ages between 4-5 years old were obtained from separate bamboo clumps. The culms were cut at about $300 \mathrm{~mm}$ above the ground. The total length of each culm was measured and then divided into three segments namely bottom, middle and top.

\section{Preparation of specimens}

\section{Wettability properties}

For each species, the middle internode of each culm segment was determined and marked (Figure 1). A $127 \mathrm{~mm}$ long segment was cut out from the selected middle internode using a mechanized pole cutter. The segment was then split using a sharp bamboo to give four slats. The inside and outside skin of each slat was removed and a $25 \mathrm{~mm}$ long sample was cut from one end for physical property determination. The remaining piece with a dimension of $5 \times 25 \times$ $101 \mathrm{~mm}$ was used for wettability property test after conditioning to 5-8\% moisture content.

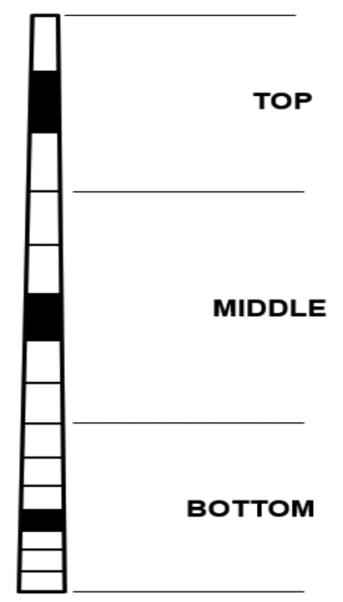

Figure 1 Selection of middle internode from each culm segment to prepare specimens for the contact angle measurements and physical property tests 


\section{Physical properties}

Moisture content was determined using the procedure described in ASTM D143-94 (ASTM 2000). The volume of the test samples was determined by the "displacement method." The density of each sample was determined as the ratio of the conditioned weight to the volume at test.

\section{Set up for contact angle measurement}

A camera with a macro lens was attached on a tripod with a lens distance of $200 \mathrm{~mm}$ from the edge of the bamboo was used to take clear photographs (Sucipto et al. 2018). The distance between the bamboo surface and the tuberculin mouth was at $20 \mathrm{~mm}$ and the droplet volume was approximately $0.01 \mathrm{~mL}$.

\section{Contact angle measurement}

Sanding was carried out after the bamboo samples were conditioned. Both untreated and treated samples were lightly sanded for 30 times using 120-grit sandpaper. A polyvinyl acetate dispersion (PVA) adhesive was used for contact angle measurement since it is used in the manufacturing of engineered bamboo products in the Philippines. PVA is a popular adhesive because of its low cost (Alipon \& Cabangon 2013). Specification of PVA wood glue is shown in Table 1. Contact angle measurement was performed on both the outside and inside layer of each test bamboo slat. There were 72 samples (36 per species) with six testing points (three for outside surface, and three for inside surface) for each sample. A photograph was taken at 2 seconds after the adhesive was dropped at each test point (Figure 2). The evaluation of the contact angles was carried out using Image $\mathrm{J}$ software ver. 1.52.

Table 1 Adhesive properties of polyvinyl acetate (PVA) wood glue

\begin{tabular}{ll}
\hline Property & \\
\hline Color & White (transparent when dry) \\
Viscosity (mPa's) & Approx. 150 \\
pH value & Approx. 7 \\
Solid content (\%) & 50 \\
\hline
\end{tabular}

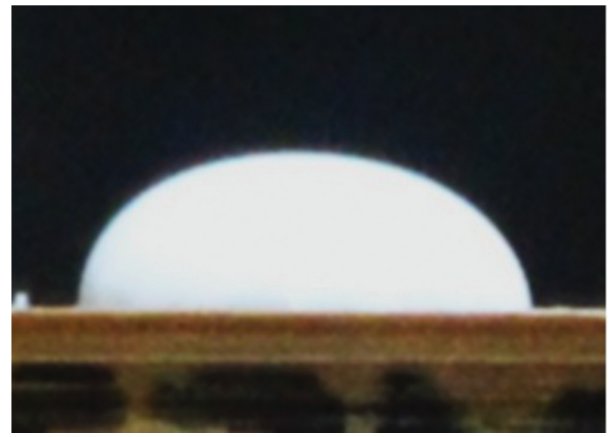

Figure 2 Sample photograph of adhesive droplet on the surface of the bamboo

\section{Thermal treatment}

The same bamboo samples were placed in an oven and treated at a temperature of $160{ }^{\circ} \mathrm{C}$ for 2 hours until the color turned brown (Shangguan et al. 2016). The treated samples were conditioned to $5-8 \%$ moisture content. The measurement of contact angle was then carried out.

\section{Statistical analysis}

Analysis of variance (ANOVA) in complete randomized design (CRD) was used to analyze the results for both species. Further analysis was conducted by using a Tukey's HSD test. Statistically significant was set at the $95 \%$ confidence level. All the statistical analysis was done using R-studio ver. 3.6.0 (R Core Team 2019).

\section{RESULT AND DISCUSSION}

\section{Wettability property of $D$. asper and B. blumeana}

The result of the ANOVA and Tukey's HSD test of the contact angle measurements were shown in Table 2 and 3. Figure 3 and 4 showed the comparison of the contact angle of D. asper and B. blumeana for untreated and thermally-treated samples at different culm height levels and culm wall layers. Figure 5 showed the density of both untreated and thermally-treated samples for both species of bamboo at different culm height levels.

All height levels and layers, the contact angle of untreated $D$. asper with an average of $107.76^{\circ}$, was significantly lower compared to untreated B. blumeana with an average of $112.17^{\circ}$ (Table 3). At different height levels, the contact 
Table 2 Analysis of variance (ANOVA) of contact angle of D. asper and B. blumeana as a function of species, height levels, layers, treatments and interaction among the four variables

\begin{tabular}{lccc}
\hline Source of variation & DF & F-value & p-value \\
\hline Species $(D$. asper \& B. blumeana) & 1 & 35.14 & $9.56 \mathrm{e}-09 * *$ \\
Height levels (bottom, middle \& top) & 2 & 7.22 & $0.0008^{* *}$ \\
Layers (inside \& outside) & 1 & 56.91 & $7.37 \mathrm{e}-13 * *$ \\
Treatments (without \& with thermal treatment) & 1 & 48.35 & $2.80 \mathrm{e}-11^{* *}$ \\
Species $\times$ height levels & 2 & 8.96 & $0.0001 * *$ \\
Species $\times$ layers & 1 & 0.43 & $0.5115^{\mathrm{ns}}$ \\
Species $\times$ treatments & 1 & 0.25 & $0.6177^{\mathrm{ns}}$ \\
Height levels $\times$ layers & 2 & 0.48 & $0.6172^{\mathrm{ns}}$ \\
Height levels $\times$ treatments & 2 & 1.64 & $0.1959^{\mathrm{ns}}$ \\
Layers treatments & 1 & 0.43 & $0.5126^{\mathrm{ns}}$ \\
Species $\times$ height levels $\times$ layers & 2 & 4.51 & $0.0119 *$ \\
Species $\times$ height levels $\times$ treatments & 2 & 1.15 & $0.3195^{\mathrm{ns}}$ \\
Species $\times$ layers $\times$ treatments & 1 & 2.52 & $0.1134^{\mathrm{ns}}$ \\
Height levels $\times$ layers $\times$ treatments & 2 & 3.11 & $0.0460^{\mathrm{ns}}$ \\
Species $\times$ height levels $\times$ layers $\times$ treatments & 2 & 0.34 & $0.7110^{\mathrm{ns}}$ \\
Error & 264 & & \\
Total & & & \\
\hline
\end{tabular}

** = significant at $1 \%$ level of probability, $*$ = significant at $5 \%$ level of probability ns = not significant

Table 3 Tukey's HSD of contact angle $\left(^{\circ}\right)$ of D. asper and B. blumeana at different height levels, layers and treatments

\begin{tabular}{lcc}
\hline \multirow{2}{*}{ Factors } & \multicolumn{2}{c}{ Mean contact angle $\left(^{\circ}\right)$} \\
\cline { 2 - 3 } Height levels & D. asper & B. blumeana \\
$\quad$ Bottom & $103.17^{\mathrm{b}}$ & $106.77^{\mathrm{b}}$ \\
Middle & $103.70^{\mathrm{b}}$ & $113.21^{\mathrm{a}}$ \\
Top & $107.31^{\mathrm{a}}$ & $108.66^{\mathrm{b}}$ \\
Layers & & \\
Outside & $107.53^{\mathrm{a}}$ & $112.88^{\mathrm{a}}$ \\
Inside & $101.92^{\mathrm{b}}$ & $106.21^{\mathrm{b}}$ \\
Treatments & & \\
Treated & $101.69^{\mathrm{a}}$ & $106.92^{\mathrm{a}}$ \\
Untreated & $107.75^{\mathrm{b}}$ & $112.17^{\mathrm{b}}$ \\
\hline
\end{tabular}

Means within the same row for each property followed by the same letter are not significantly different 


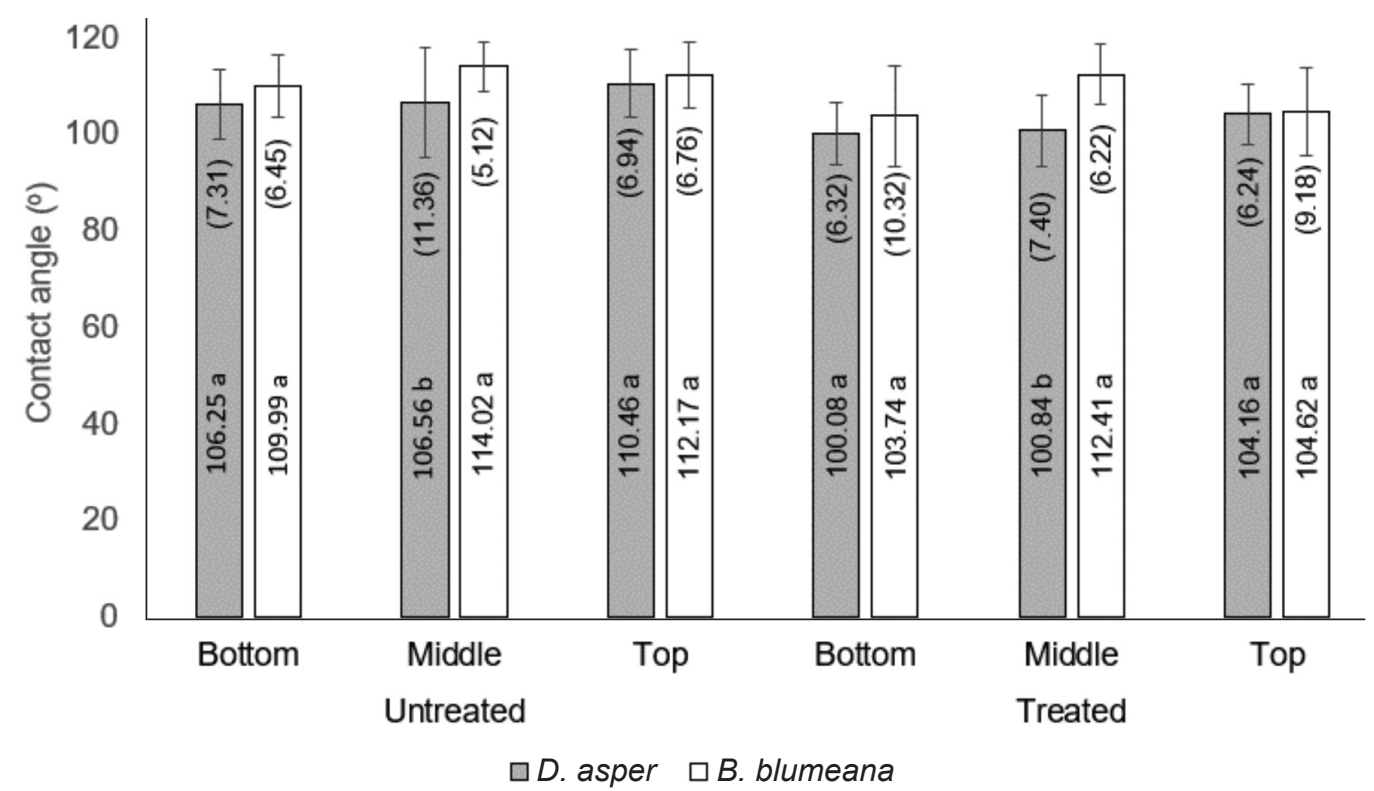

Values in parentheses are standard deviation; means with the same letter are not significantly different from each other at $95 \%$ confidence level

Figure 3 Comparison of contact angle of D. asper and B. blumeana for untreated and thermally treated samples at different height levels

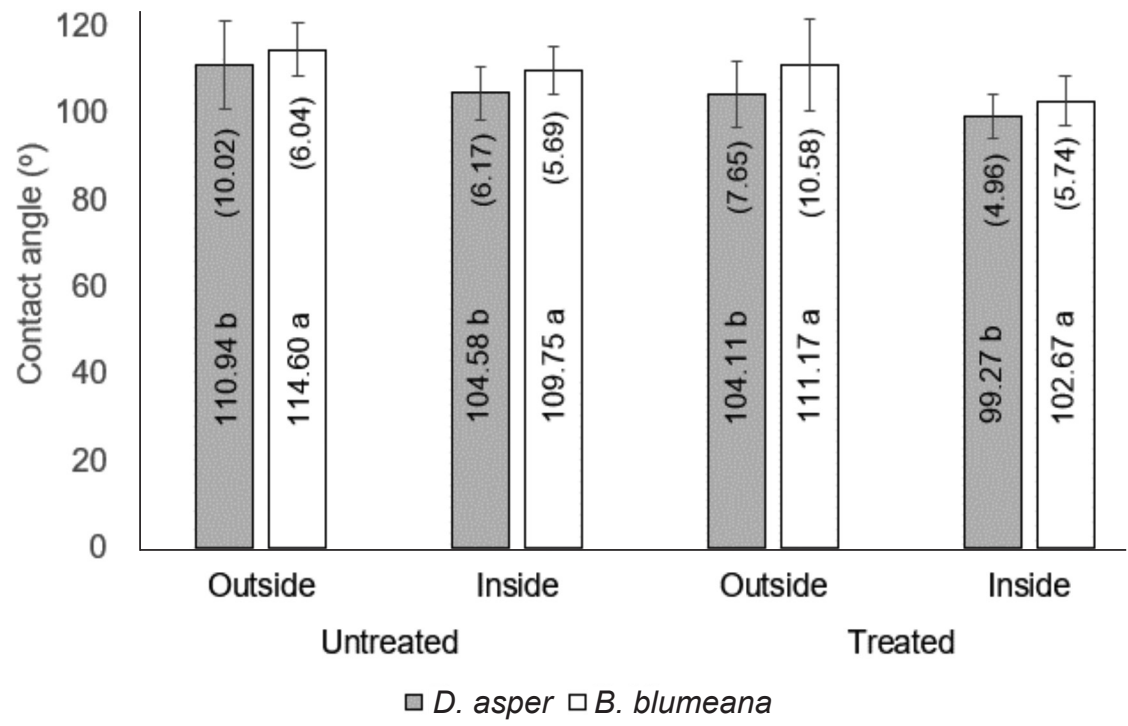

Values in parentheses are standard deviation; means with the same letter are not significantly different from each other at $95 \%$ confidence level

Figure 4 Comparison of contact angle of D. asper and B. blumeana for untreated and thermally treated samples at different layers

angles for untreated $D$. asper and B. blumeana were significantly different only at the middle portion of the culms. This was supported by the ANOVA which showed the culm height level was a significant factor affecting contact angles in $D$. asper and B. blumeana $(p=0.0008)$. The interactions of species $\times$ height levels $(p=0.0001)$ and species $\times$ height levels $\times$ layers $(p=0.0119)$ were likewise significant, suggesting that these contributed to the variability in the contact angles.

The top portion of $D$. asper gave significantly higher contact angle compared to the other portions (Table 3 ). However, the contact angles for the bottom and middle portions were not 


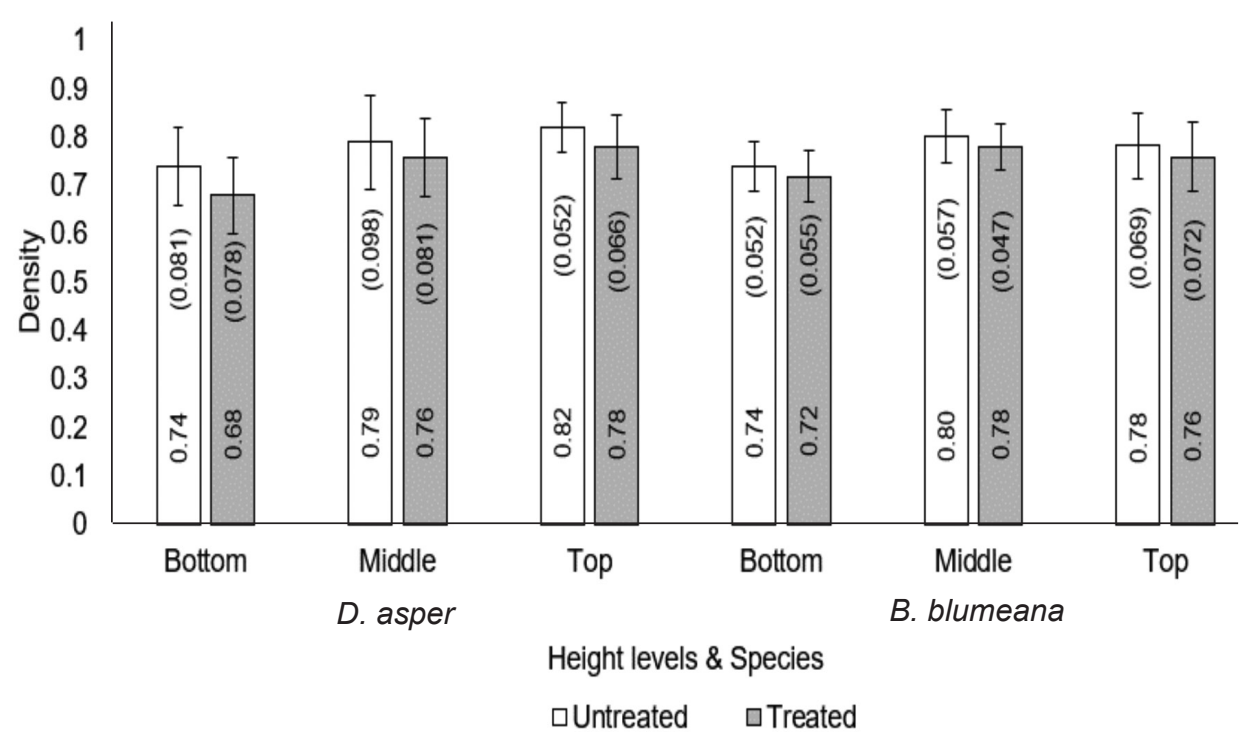

Values in parentheses are standard deviation; there are no significant differences between means

Figure 5 Effect of thermal treatment on the density of D. asper and B. blumeana

significantly different from each other. In the case of B. blumeana, the contact angle of the middle portion was significantly higher than the bottom and top portions. The difference in contact angle could be explained in terms of the difference in density at different culm height levels (Figure 5). This corroborated the earlier studies in D. strictus (Ahmad \& Kamke 2003), Gigantochloa scortechinii (Anwar et al. 2004) and D. asper (Chaowana et al. 2012) that showed increasing contact angles as density increased.

Sucipto et al. (2018) stated that materials with low density had better wettability properties. This study found the density of $D$. asperincreased from the bottom to the top, while in B. blumeana the middle portion had the highest density. The findings supported the results previously reported by Sucipto et al. (2018). Variation in the density of bamboo taken from different culm height levels was due to the changing proportion, size of vascular bundles, and percentage of silica content. Studies by Siam et al. (2019) showed the vascular bundle area of $D$. asper from bottom to top portion were 10,12 and $16 \mathrm{~mm}^{-2}$ respectively. In $B$. blumeana, the corresponding values were 10,15 and $18 \mathrm{~mm}^{-2}$ respectively. Generally, bamboo with high density was harder and negatively affecting the penetration of adhesive that resulted in a high contact angle. High silica content also contributed to the increase in contact angle and lower wettability property (Faizal et al. 2015).
The contact angle of $D$. asper and B. blumeana also exhibited significant differences between the layers $\left(p=7.37 \mathrm{e}^{-13}\right)$. The average contact angle of the outer layer of $D$. asper at $110.94^{\circ}$ and B. blumeana at $114.60^{\circ}$ was significantly higher compared to that of the inner portion at $104.58^{\circ}$ and $109.75^{\circ}$ for D. asper and B. blumeana respectively (Figure 4 ).

Higher contact angles in the outside layer were previously observed in $D$. sericeus (Chaowana et al. 2015), D. asper, B. arundinaceae and Guadua angustifolia (Li et al. 2004). The results indicated that the outside layers of $D$. asper and B. blumeana were more difficult to be wetted than the inside layer. A large contact angle indicated low wettability causing penetration of adhesive and liquids would be difficult.

The difference between the contact angle of the outside and inside layer was due to variation in their density (Chaowana et al. 2015). The outside layer was denser than the inside portion due to the high occurrence of vascular bundles and low distribution of parenchyma cells in the outside layer. It was also hydrophobic due to its high silica content (Faizal et al. 2015). These factors made the outer layer more difficult to be penetrated by liquid, consequently resulting in a higher mean contact angle ( $\mathrm{Li}$ et al. 2004). The difference in the extractive content might also affect the wettability properties of bamboo layers as its outside layer possessed higher extractive content (Faizal et al. (2015). 


\section{Effect of thermal treatment on wettability property of $D$. asper and $B$. blumeana}

The thermal treatment on $D$. asper and $B$. blumeana significantly reduced the contact angle of both species $\left(p=2.80 \mathrm{e}^{-11}\right)$. The observed contact angle in the treated slats was lower than the untreated slats (Figure 3 and 4).

After thermal treatment, the contact angle of $D$. asper decreased from $101.76^{\circ}$ to $101.69^{\circ}$ (a $5.63 \%$ reduction) and for $B$. blumeana, the decrease was from $112.17^{\circ}$ to $106.92^{\circ}$ (a $4.68 \%$ reduction). For the culm height levels, the highest reduction was found in the both bottom portions of D. asper (5.80\%) and B. blumeana $(5.52 \%)$ respectively. For the layers, a higher reduction was observed in the outside layer $(6.15 \%)$ for $D$. asper and the inside layer $(6.45 \%)$ for B. blumeana.

As in the case of the untreated bamboo, the top portion of $D$. asper and middle portion of B. blumeana gave significantly higher contact angle measurements than the other portions. A high mean contact angle was retained by the outside layer for both species of bamboo after the thermal treatment.

The significant reduction in the contact angle for both bamboo species could be attributed to the decrease in density after thermal treatment as material degradation was observed in the bamboo due to high temperature.

The decrease in density and contact angle was also observed in compressed oil palm trunk using phenol-formaldehyde after exposure to $120^{\circ} \mathrm{C}$ and a pressure of $25 \mathrm{~kg}$ for 30 mins (Sucipto et al. 2018). Furthermore, the decrease in contact angle was also seen in Neosino calamus affinis (Shangguan et al. 2016) and P. pubescens (Shah et al. 2018) after being subjected to heat treatment. The decrease in contact angle in treated bamboo was caused by the reduction in the hydrophobicity of bamboo fibers, higher polarity and surface energy after exposure to high heat treatment (Shah et al. 2018).

High temperature caused damage to crystalline cell wall structure, resulting in increased moisture content, absorption and wettability property of the materials (Liu and Zhao 2004). The crystallinity of the cell wall decreased due to depolymerization and degradation in both crystalline and amorphous regions (Akgül et al. 2007). The decrease in density and degradation of chemical structure could also be the reason for the increase in hygroscopicity of bamboo after heat treatment (Shangguan et al. 2016).
The average contact angle of treated B. blumeana $\left(106.92^{\circ}\right)$ was significantly higher than D. asper $\left(101.69^{\circ}\right)$ for treated samples (Table 3). On the other hand, Figures 3 and 4 showed that B. blumeana slats gave higher contact angles at different height levels and layers than $D$. asper. The observed contact angles of both untreated and treated D. asper and B. blumeana were higher compared to wood species such as P. falcataria $\left(90.11^{\circ}\right)$ and Shorea sp. $\left(83.00^{\circ}\right)$ (Sucipto et al. 2018).

The observations reported in the present study differed from the other studies. Previous studies by Hou et al. (2011), Li et al. (2015) and Zhang \& Yu (2015) showed a significant increase in the contact angle after the thermal treatment of Phyllostachys pubescens. Similarly, an increase in contact angle was observed in beach wood (Hakkou et al. 2005), spruce, poplar, beech and pine (Petrissans et al. 2003), Pinus pinaster and Eucalyptus globules (Esteves et al. 2007) after heat treatment. They concluded that the increase in contact angle after heat treatment might be due to plasticization of lignin which led to a reorganization of lignocellulosic polymeric components.

Treated and untreated B. blumeana were predicted to have poor surface wettability and weak bonding properties due to higher contact angle as compared to $D$. asper. Thus, both untreated and treated $D$. asper would have better penetration by glue and higher bonding strength as compared to B. blumeana.

Based on the findings, it was recommended that additional surface treatment be performed on the outside layer to improve its wettability and comparable with the inside layer of an assembled construction layered bamboo. Previous study by Chaowana et al. (2015) indicated that lower physical and mechanical properties were observed in outside-outside layer than the insideinside layer combination of laminated bamboo lumber made from D. sericeus. Anwar et al. (2012) also reported that the internal bond of bamboo zephyr board and shear property of plybamboo decreased when the bamboo was laid based on outside-outside layer.

\section{Effect of thermal treatment on the physical properties of $D$. asper and B. blumeana}

There was no significant decrease in density of both bamboos after thermal treatment (Figure $5)$. In contrast, the bottom portion of $D$. asper 
showed significant reduction in density as a result of thermal treatment.

A similar decrease in density after exposure to high temperature was observed in B. blumeana (Natividad \& Jimenez, 2015) and N. calamus affinis (Shangguan et al. 2016). The density of wood exposed to high temperature decreased due to thermal degradation of the components and had negatively affected its mechanical properties (Sinha et al. 2010).

Bremer et al. (2013) explained that the decrease in density of bamboo after heat treatment was due to the mass loss owing to the decomposition of hemicelluloses at very high temperature. This finding conformed to the study of Windeisen et al. (2007), where the decrease in density was due to chemical modification of cellulose and hemicellulose as they were more susceptible to thermal degradation than the other components.

In a study by Zhang et al. (2013), the reduction of $26.3 \%$ and $52.9 \%$ were observed in bamboo cellulose and hemicellulose respectively after thermal treatment above $160^{\circ} \mathrm{C}$. Meng et al. (2016) discovered that the bamboo cellulose decreased from $41.54 \%$ to $26.61 \%$ as the temperature increased from ambient temperature to $200{ }^{\circ} \mathrm{C}$.

Another noticeable difference between the untreated and thermally-treated samples of $D$. asper and B. blumeana was the color change in species after thermal treatment (Figure 6).
Untreated samples were light in color, but the thermally-treated samples turned bright brown after being subjected to $160^{\circ} \mathrm{C}$ for 2 hours. Similarly, N. calamus affinis (Shangguan et al. 2016), B. blumeana (Natividad \& Jimenez, 2015) and $P$. pubescens (Shah et al. 2018) also changed color after heat treatment.

The color change in bamboo from light to dark brown could possibly be due to the chemical reaction of lignin during the heat treatment. A typical Gramineae lignin was composed of a mixture of phenylpropanoid compounds with chromophoric groups (Shao et al. 2008). Lignin was relatively stable at room temperature but was quickly oxidized, forming chromophoric groups in high temperature (Sharratt et al. 2009).

Exposing bamboo slats to a temperature of $160{ }^{\circ} \mathrm{C}$ for 2 hours might have resulted in the degradation of materials in both bamboos. However, the temperature was not high enough to produce significant differences in density at different height levels in both bamboos. In a study by Natividad \& Jimenez (2015), a significant decrease in the relative density of B. blumeana was observed at $200{ }^{\circ} \mathrm{C}$ for 1 hour. In addition, a significant change in the mass of Neosino calamus affinis was found at a temperature between 170 and $230{ }^{\circ} \mathrm{C}$ for 2 hours.

The color changes improved the aesthetic value of bamboo without sacrificing its mechanical properties. It was noted that although the relative density decreased, the values were not statistically

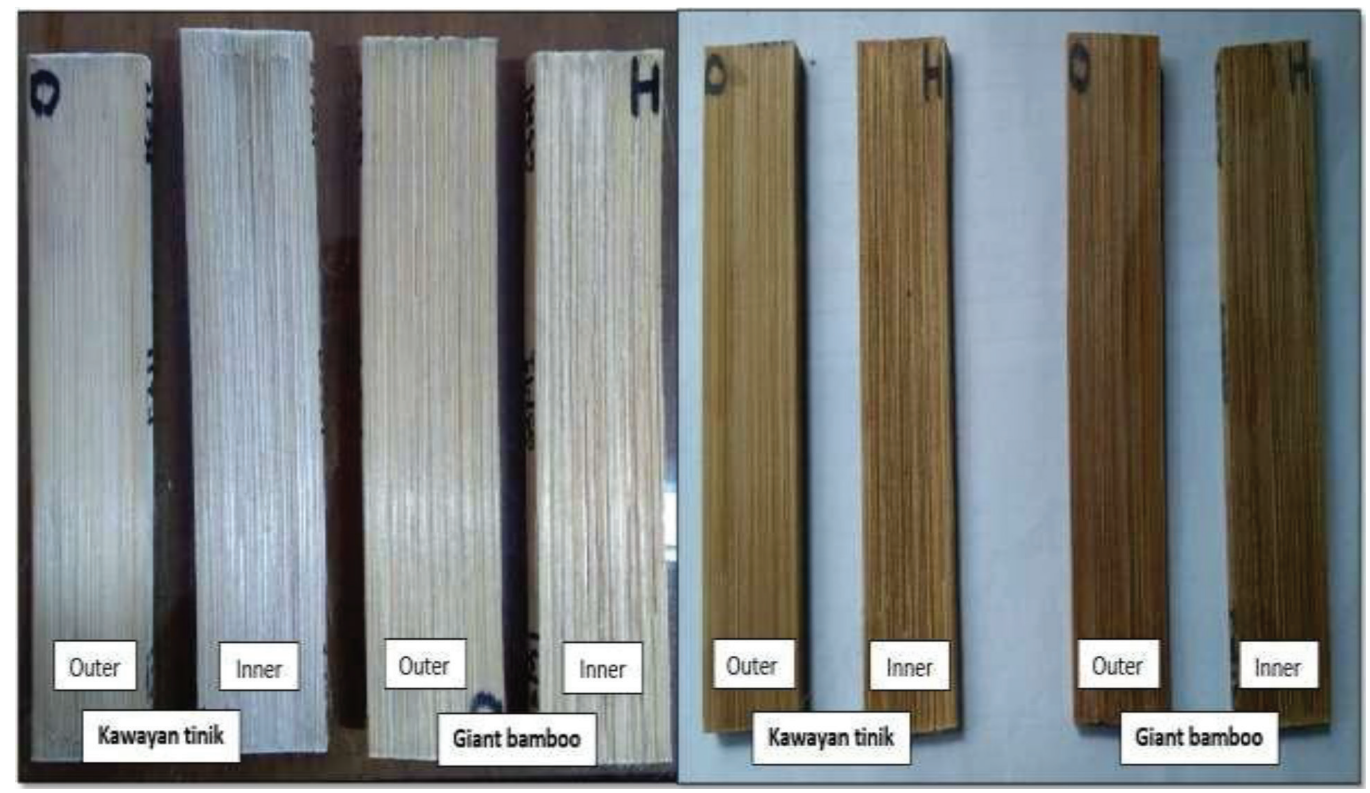

Figure 6 Difference in color of Kawayan tinik (B. blumeana) and Giant bamboo (D. asper) before (left panel) and after (right panel) thermal treatment 
significant after heat exposure at $160{ }^{\circ} \mathrm{C}$ for 2 hours.

\section{CONCLUSION}

Both the untreated and thermally-treated $D$. asper possessed better wettability compared to B. blumeana as shown by the contact angle measurements. At different height levels, the top portion of $D$. asper and middle portion of $B$. blumeana had significantly higher contact angles and densities, which could imply that they had lower wettability compared to the other culm portions. The inside layer of both bamboos had better wettability compared to the outside layer.

Color variation and reduction in density were observed after the thermal treatment for both bamboo species. Due to material degradation, the decrease in contact angle had helped in improving the wettability property of both bamboos.

Thermal treatment with temperature at $160{ }^{\circ} \mathrm{C}$ for 2 hours helped to improve the aesthetic value of both bamboos by changing the color without significant reduction in density. Thus, exposure of both bamboos at this temperature would not dramatically affect the mechanical properties. Further studies employing several combinations of temperature and duration of treatment are needed to optimize the process.

\section{ACKNOWLEDGMENT}

The authors were grateful to the Philippine Council for Agriculture, Aquatic, and Natural Resources Research and Development of the Department of Science and Technology for the funding through the GREAT Scholarship Grant given to Mr. Marasigan. Sincere appreciation to the Department of Science and Technology Forest Products Research and Development Institute and the UPLB College of Forestry and Natural Resources Forest Products and Paper Science Department for the use of facilities and equipment. Mr. Marasigan was also grateful and was blessed by Ms. L. S. Teodosio for her support during the conduct of the study.

\section{REFERENCES}

Ahmad M \& Kamke FA. 2003. Analysis of Calcutta bamboo for structural composite materials: Surface characteristics. Wood Science and Technology 37: 233240. https://doi.org/10.1007/s00226-003-0172-x.
Akgül ME, GümüşKaya \& Korkut S. 2007. Crystalline structure of heat-treated Scots pine [Pinus sylvestris L.] and Uludağ fir [Abies nordmanniana (Stev.) subsp. bornmuelleriana (Mattf.)] wood. Wood Science and Technology. 41: 281-289. https://doi.org/10.1007/ s00226-006-0110-9.

Alipon MA \& Cabangon RJ. 2013. Generation of technical basis for the development of standards for engineered bamboo (E-bamboo). Philippine Journal of Science 142: 143-152.

Anwar UMK, Paridah MT, Hamdan H et al. 2012. Adhesion and bonding properties of low molecular weight phenol formaldehyde-treated plybamboo. Journal of Tropical Forest Science 24: 379-386.

Anwar UMK, Zaidon A, Paridah MT et al. 2004. The potential of utilising bamboo culm (Gigantochloa scortechinii) in the production of structural plywood. Journal of Bamboo and Rattan 3: 393-400. https:/ / doi. org/10.1163/1569159042464653.

American Society for Testing and Materials (ASTM). 2000. Standard Methods of Testing Small Clear Specimens of Timber. ASTM Designation: D143-94. Pp. 25-55 in Annual Book of ASTM Standards, Section 4, Vol. 04.10. West Conshohocken, PA, USA.

Baja-Lapis A, Palijon AM, Tesoro FO et al. 2016. Bamboo: The Grass of Hope. Philippine Bamboo Foundation. Philippines.

Bremer M, Fischer S, Nguyen TC et al. 2013. Effects of thermal modification on the properties of two Vietnamese bamboo species. Part II: Effects on chemical composition. BioResources 8: 981-993. https://doi.org/10.15376/biores.8.1.981-993.

Chaowana P, Robkorb K, Sriwilai S et al. 2012. Gluability variation of Dendrocalamus asper for bamboo composites. Pp 307-315 in Johan G. (eds). Proceeding of the $9^{\text {th }}$ World Bamboo Congress. 10-15 April 2012, Belgium.

Chaowana P, Jindawong K \& Sungkaew S. 2015. Adhesion and bonding performance of laminated bamboo lumber made from Dendrocalamus sericeus in Proceedings of the $10^{\text {th }}$ World Bamboo Congress. 17-22 September 2015, Korea. https://worldbamboo.net/proceedings/ wbcx.

Esteves B, Marques AV, Domingos I et al. 2007. Influence of steam heating on the properties of pine (Pinus pinaster) and eucalypt (Eucalyptus globulus) wood. Wood Science and Technology 41: 193-207. https:/ / doi. org/10.1007/s00226-006-0099-0.

Faizal W, Wahid AB, Ahmad M et al. 2015. Contact angle of different portions of Beting bamboo (Gigantochloa levis) treated with maleic anhydride for composite materials. International Journal of Mechanical and Production Engineering 3: 68-70.

Gupta AK, Ganguly R \& Mehra AS. 2015. Bamboo as green alternative to steel for reinforced concrete elements of a low-cost residential building. Electronic Journal of Geotechnical Engineering 20: 1523-1545.

Hakkou M, Pétrissens M, Zoulalian A et al. 2005. Investigation of wood wettability changes during heat treatment on the basis of chemical analysis. Polymer Degradation and Stability 89: 1-5.

Hou LY, AN ZH, ZHaO RJ ET AL. 2011. Effects of steam heating treatment and xenon irradiation on surface color 
of Moso bamboo. Journal of Fujian Forestry College 31: 177-180.

Li T, Li Cheng D, WÅLInder MEP et AL. 2015. Wettability of oil heat-treated bamboo and bonding strength of laminated bamboo board. Industrial Crops and Products 69: 15-20. https://doi.org/10.1016/j. indcrop.2015.02.008.

Li XB, Shupe TF \& Hse CY. 2004. Wettability of three Honduran bamboo species. Journal of Bamboo and Rattan 3: 159 167. https://doi.org/10.1163/156915904774195151

Liu YX \& Zhao GJ. 2004. Wood Materials Science. Chinese Forestry Press, Beijing.

Marra AA. 1992. Technology of Wood Bonding: Principles in Practice, Van Nostrand Reinhold, New York.

Meng FD, Yu YL, Zhang YM et al. 2016. Surface chemical composition analysis of heat-treated bamboo. Applied Surface Science 371: 383-390. https://doi. org/10.1016/j.apsusc.2016.03.015.

Natividad RA \& Jimenez JP. 2015. Physical and mechanical properties of thermally modified Kauayan tinik (Bambusa blumeana Schultes f.) in Proceedings of the $10^{\text {th }}$ World Bamboo Congress. 17-22 September 2015, Korea. https://worldbamboo.net/proceedings/ wbcx

Pétrissans M, Gérardin P, El Bakali I et al. 2003. Wettability of heat-treated wood. Holzforschung 57: 301-307. http://dx.doi.org/10.1515/HF. 2003.045.

R Core Team. 2019. R: A language and environment for statistical computing. R Foundation for Statistical Computing, Vienna, Austria. URL https://www.Rproject.org/.

Roxas CA. 2012. Handbook on Erect Bamboo Species Found in the Philippines. Ecosystems Research and Development Bureau, Department of Environment and Natural Resources. College, Laguna.

Shah DU, Sharma B \& Ramage MH. 2018. Processing bamboo for structural composites: Influence of preservative treatments on surface and interface properties. International Journal of Adhesion and Adhesives 85: 15-22. https://doi.org/10.1016/j. ijadhadh.2018.05.009.

Shangguan W, Gong Y, Zhao R et al. 2016. Effects of heat treatment on the properties of bamboo scrimber. Journal of Wood Science 62: 383-391. https://doi. org/10.1007/s10086-016-1574-3.

Shao S, Wen G \& Jin Z. 2008. Changes in chemical characteristics of bamboo (Phyllostachys pubescens) components during steam explosion. Wood Science and Technology 42: 439-451. https://doi.org/10.1007/ s00226-008-0183-8.
Sharratt V, Hill CAS \& Kint DPR. 2009. A study of early colour change due to simulated accelerated sunlight exposure in Scots pine (Pinus sylvestris). Polymer Degradation and Stability 94: 1589-1594. https://doi. org/10.1016/j.polymdegradstab.2009.04.010.

SHEN Y, WANG Y, TANG YET AL. 2013. The induced discoloration mechanism of high temperature heat-treated bamboo. Journal on Bamboo Resources 32: 42-45.

Siam NA, Uyup MK, Husain H ET AL. 2019. Anatomical, physical and mechanical properties of thirteen Malaysian bamboo species. BioResources 14: 3925-3943.

Sinha A, Gupta R \& Nairn JA. 2010. Effect of heat on the mechanical properties of wood and wood composites. Pp 661-668 in Ceccotti A. (ed) The 11th World Conference on Timber Engineering 2010, WCTE 2010, 20-24 June 2010, Riva del Garda, Italy.

Sucipto T, Hartono R \& Dwianto W. 2018. Determination of wood wettability properties of oil palm trunk, Shorea sp. and Paraserianthes falcataria by contact angle method. IOP Conference Series: Earth and Environmental Science 122: 1-8. https://doi.org/10.1088/1755$1315 / 122 / 1 / 012141$.

SucIPTo T. 2009. Determinasi Keterbasahan (Wettability) Kayu. http://repository.usu.ac.id/bitstream/123456789/ 1035/1/10E00550.pdf.

Tomak ED, Ustaomer D, Yildiz S et al. 2014. Changes in surface and mechanical properties of heattreated wood during natural weathering. Measurement: Journal of the International Measurement Confederation 53: 30-39. https://doi.org/10.1016/j. measurement.2014.03.018.

Wahab R, Mohamed A, Mustafa MT et al. 2009. Physical characteristics and anatomical properties of cultivated bamboo (Bambusa vulgaris Schrad.) culms. Journal of Biological Sciences 9: 753-759. https://doi. org/10.3923/jbs.2009.753.759.

Windeisen E, Strobel C \& Wegener G. 2007. Chemical changes during the production of thermo-treated beech wood. Wood Science and Technology 41: 523-536. https://doi.org/10.1007/s00226-007-0146-5.

Zhang Y \& YU W. 2015. Changes in surface properties of heattreated Phyllostachys pubescens Bamboo. BioResources 10: 6809-6818. https://doi.org/10.15376/ biores.10.4.6809-6818.

ZHANG YM, YU YL \& YU WJ. 2013. Effect of thermal treatment on the physical and mechanical properties of Phyllostachys pubescens bamboo. European Journal of Wood and Wood Products 71: 61-67. https://doi. org/10.1007/s00107-012-0643-6. 